$1-1-2009$

\title{
HIV and AIDS Stigma and Discrimination in China: Results from a National Survey
}

Karen Hardee

Tim Manchester

Victor Yuan

Benjamin Y. Clark

Cleveland State University, b.y.clark@csuohio.edu

Amy Qi

See next page for additional authors

Follow this and additional works at: https://engagedscholarship.csuohio.edu/urban_facpub

Part of the Urban Studies and Planning Commons

How does access to this work benefit you? Let us know!

\section{Repository Citation}

Hardee, Karen; Manchester, Tim; Yuan, Victor; Clark, Benjamin Y.; Qi, Amy; Bradley, Sarah; and Shen, Zoe, "HIV and AIDS Stigma and Discrimination in China: Results from a National Survey" (2009). All Maxine Goodman Levin School of Urban Affairs Publications. 0123700.

https://engagedscholarship.csuohio.edu/urban_facpub/700

This Article is brought to you for free and open access by the Maxine Goodman Levin School of Urban Affairs at EngagedScholarship@CSU. It has been accepted for inclusion in All Maxine Goodman Levin School of Urban Affairs Publications by an authorized administrator of EngagedScholarship@CSU. For more information, please contact library.es@csuohio.edu. 


\section{Authors}

Karen Hardee, Tim Manchester, Victor Yuan, Benjamin Y. Clark, Amy Qi, Sarah Bradley, and Zoe Shen 


\section{Cleveland State University}

From the SelectedWorks of Benjamin Y. Clark

January 2009

HIV and AIDS Stigma and Discrimination in China: Results from a National Survey

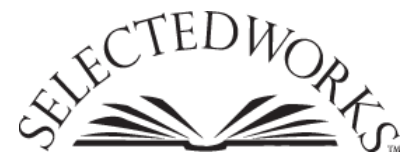

Available at: http://works.bepress.com/benjamin_clark/2 


\section{HIV and AIDS Stigma and Discrimination in China: Results from a National Survey}

Because stigmatizing and discriminatory attitudes and tendencies are largely prevalent in China, national and local mass media interventions have an important role to play in making Chinese citizens aware

of the debilitating effects of stigma and discrimination and in reinforcing information on HIV/AIDS to reduce baseless fears of transmission.

By Karen Hardee, Benjamin Y. Clark, Victor Yuan, Tim Manchester, Amy Qi, Sarah E.K. Bradley and Zoe Shen*

Worldwide, stigma and discrimination have been identified as tremendous barriers to addressing the HIV/AIDS epidemic, beginning with Jonathan Mann in the 1980s (Mann, 1987), and by others (UNAIDS, 2001, 2008; Reidpath, Brijnath

\footnotetext{
* Karen Hardee, Population Action International, Washington, D.C.-Formerly of Futures Group International when this work was conducted; Benjamin Y. Clark, Department of Public Administration and Policy, University of Georgia, Athens, Georgia, United States of America, e-mail: benclark@uga.edu; Victor Yuan and Zoe Shen, Horizon Research Consultancy Group, Beijing, China; Tim Manchester, United States Agency for International Development, Dar es Salaam, Tanzania—Formerly of Futures Group International when this work was conducted; Amy Qi, Futures Group International, Beijing; and Sarah E.K. Bradley, Macro International, Washington, D.C.
} 
and Chan, 2005; APN+, 2004). Stigma was defined by Goffman (1963) nearly half a century ago as a discrediting attribute about an individual or group that serves to devalue that person or group in the eyes of the society. More recent theoretical frameworks suggest that stigmatization and discrimination are manifest in a number of contexts, including within families, communities, schools, employment, travel/ migration opportunities, health-care settings and HIV/AIDS programmes (Parker and Aggleton, 2002), and in religion and the media (Malcolm and others, 1998). A study in four countries in Asia found pervasive discrimination, with 80 per cent of respondents having experienced AIDS-related discrimination, including nearly one in five facing discrimination within their families and in their workplaces (APN+, 2004). In a review of interventions to reduce HIV/AIDS stigma, Brown, MacIntyre and Trujillo (2003) noted that stigma affects prevention behaviours, test-seeking, care-seeking, quality of care provided to positive clients, and perceptions and treatment of people living with HIV and AIDS by communities and families. Parker and others (2002) contend that HIV/AIDS-related stigma is often layered upon other stigma, for example, the one associated with engaging in illegal behaviour, such as sex work and drug use. Furthermore, families with HIV-positive members often face stigma from the community. In order to combat stigma and the associated discrimination, it is important to understand the knowledge, beliefs and attitudes and how they vary across groups within a country. Such knowledge is critical for designing interventions to reduce stigma and discrimination.

While HIV prevalence in China is still low nationally (less than 0.1 per cent), the country is home to an estimated 840,000 people living with HIV and AIDS (UNAIDS, 2006). In China, HIV and AIDS have long been associated with marginalized groups, including some engaging in illegal behaviour. Of those living with HIV and AIDS in 2005, 44 per cent are injecting drug users and 20 per cent are sex workers and their partners. Eleven per cent acquired HIV through the illegal sale of blood and 7 per cent are men who have sex with men. A further 17 per cent are partners of HIV-infected individuals and members of the general population, while 1 per cent of infections were a result of mother-to-child transmission of HIV (UNAIDS, 2006).

The Government of China was slow in responding to HIV and AIDS (Kaufman and Jing, 2002). The first case of HIV was reported in the 1980s but a national plan was not issued until 2001. Partly as a result of years without national attention drawn to HIV and AIDS, knowledge of HIV is superficial at best and lack of accurate information is common. 
Anecdotal evidence suggests that negative attitudes are widespread in China. Gill (2002) noted "widespread social discrimination against HIV and AIDS victims". Avert.org (2004) found that the pressure from society pushes families to either reject those with HIV and AIDS or to hide their status, even from members of their own family. Rosenthal (2003) reported that until recently, the legal system has not sufficiently protected people living with HIV and AIDS. Reidpath, Brijnath and Chan (2005) in a study of institutional discrimination in six countries in Asia-Pacific, including China, found that discrimination was most prevalent in practice rather than in laws or policies. Suzhou in Jiangsu province became the first province in China to pass a law to protect the rights of people living with HIV and AIDS (PLHA) in 2002 (Agence France Presse, 2002). Based on a large sample survey conducted in 2000, Chen and others (2005) found that community factors such as the level of HIV/AIDS-related risk behaviour and level of development in the community affected people's perceptions of an acquaintance living with HIV and AIDS.

\section{Research questions}

This paper assesses stigma and discrimination using data from a national market research omnibus survey that was conducted among Chinese men and women in 2003. Several questions on HIV and AIDS were added to the national omnibus survey by Futures Group Europe under the China AIDS Prevention and Control Programme, funded by DFID. The questions on AIDS, which included three on stigma and discrimination, were adapted from established research instruments developed under second generation surveillance (FHI and DFID, 2000; WHO, 2008). The analysis measures attitudes related to two distinct groupshow respondents would treat an HIV-positive family member and an HIV-positive co-worker at work - two contexts in which theoretical frameworks note that stigma and discrimination are manifest (Parker and others, 2002). These two contexts are critical to the well-being of PLHA because "the family is the main source of care and support for PLHA in most developing countries" (Parker and others, 2002: p. 8) and access to employment can help ensure that PLHA can have a means of independent financial support. Evidence of stigmatization and discrimination in the workplace abound, both by employers and by fellow employees (Malcolm and others, 1998; Parker and Aggleton, 2002; Pulerwitz and others, 2001; UNAIDS, 2006). Furthermore, these two contexts represent two social realms - within the family and within the broader society. The authors' primary research questions therefore are: 
1. Are there any prevailing attitudes related to people living with HIV and AIDS that are shared throughout the general public in China?

2. Are there differences in the ways people say they would or do treat people living with HIV and AIDS?

3. Are there differences in people's attitudes if the person is a co-worker or a family member?

The paper assesses the effects of age, sex, education, residence, and knowledge of HIV and AIDS on the practice of HIV and AIDS-related stigma and discrimination. ${ }^{1}$ The authors hypothesize that those less likely to engage in stigmatizing and discriminating behaviour will be younger, female, urban residents, with higher education and higher levels of knowledge of HIV and AIDS. The authors also hypothesize that women will be less stigmatizing and discriminatory because stigma is related to other social inequalities, including gender (Parker and Aggleton, 2002). Urban residents tend to have a wider range of non-family ties (White and Guest, 2003), which could make them more accepting of others. Higher education also tends to be linked to more progressive and open views. Finally, those with higher level of knowledge on HIV and AIDS should be more likely to understand the modes of transmission and have less fear of transmission through everyday contact with family members and with work colleagues.

\section{Methods}

\section{Sample}

Data in this paper were collected through a national omnibus survey that encompassed a number of topics. A small set of questions were included on the omnibus survey regarding public opinion on knowledge, attitudes and behaviours related to HIV and AIDS in China. ${ }^{2}$ The national survey was undertaken in 2003, under the auspice of the China-UK HIV Prevention and Care Project, with funding from the United Kingdom Department for International Development (DfID) and managed by Futures Group Europe (now Futures Group International). Horizon Market Research, based in Beijing, collected the data and Futures Group and Horizon Market Research jointly analysed the data.

The full sample comprised 3968 adult women and men that were included in the market research omnibus survey in seven cities, seven towns, and eight rural regions across China. The cities surveyed were: Beijing, Shanghai, Guangzhou, Wuhan, Chengdu, Shenyang and Xi'an. The rural areas were selected from the 
seven towns and one village. The towns include Zhuji (Zhejiang Shaoxing), Changle (Fujian Fuzhou), Beining (Liaoning Jinzhou), Zhuangxinji (Hebei Shijiazhuang), Linxiang (Henan Yueyang), Pengzhou (Sichuan Chengdu), Xingping (Shanxi Xianyang), and one village from Huangpi (Hubei Wuhan). The urban respondents, from cities and towns, ranged in age from 18 to 60 and the rural sample ranged from 16 to $60 .{ }^{3}$ None of the respondents had left home for long-term study.

In urban areas, the national omnibus survey included a multi-phase random sampling method, first with a neighbourhood committee sample and then with households (Horizon Research Consultancy Group and Futures Group Europe, 2004). If there were no qualified respondents in a target household, another qualified respondent was substituted. If there were more than one qualified respondents in a household, only one was interviewed, in accordance with the Kish sampling method (Kish, 1965). In rural areas, cluster sampling was used. An administrative village was chosen from every town listed above, and then two natural (geographically contiguous) rural areas were chosen from every administrative village. If there was no one in a target household by this sampling method, the interviewers were to try contacting that household every two hours, up to three times. Thereafter, if no one could be reached, a substitute household would be chosen as a replacement. In one household, if there were no qualified respondents, or if respondents refused to answer, a substitute household would be chosen to replace it (Horizon Research Consultancy Group and Futures Group Europe, 2004). Data were weighted to reflect the distribution of the Chinese population in the provinces included in the study.

All observations of individuals that indicated that they had not heard of HIV and AIDS were dropped from the sample. These individuals had not answered any of the questions related to HIV and AIDS and thus were not able to shed any light on the determinants of stigma and discrimination in China.

\section{Model specification}

\section{Definition of stigma and discrimination variables}

Stigma and discrimination was assessed through the following three questions:

- If a co-worker of yours has HIV but is not sick, should he or she be allowed to continue to work? 
- If a member of your family became ill with HIV, the virus that causes AIDS, would you want it to remain secret?

- If a family member of yours became ill with HIV, the virus that causes AIDS, would you be willing to care for him in your household?

Use of Chronbach's Alpha and factor analysis did not support development of an index of stigma and discrimination. Thus, logistic regressions were run using the three stigma and discrimination variables as the dependent variables in separate models to help assess the characteristics that affect stigma and discrimination. The models measure the likelihood of these dependent variables switching from zeros (a "no" response to the questions) to ones (a "yes" response to the questions).

\section{Independent variables:}

Age. Age was a continuous variable in the model.

Sex. The sex variable included in the analysis is male, indicating the differences between men and the omitted reference group women.

Residence. Data were collected in three general geographic regions: city, town and rural. The omitted reference group in the analysis was city residence.

Education. Education was represented by four variables in the models and one omitted reference category. The education variables found in the models were: middle school; senior middle school, secondary specialized or technical school; college; and university and above. The reference category for education was the variable indicating only an elementary school-level education.

Knowledge of HIV and AIDS. Knowledge of HIV and AIDS is measured as the number of correct answers to the seven knowledge questions below. Values of the variable ranged from zero to seven.

- Can a person get HIV by sharing a meal with someone who is infected?

- Can people reduce their chance of getting the virus that causes AIDS by not having sex at all?

- Can people reduce their chance of getting the virus that causes AIDS by having just one partner who is not infected and who has no other partners?

- Can people protect themselves from HIV, the virus that causes AIDS, by using a condom correctly every time they have sex? 
- Can people reduce their chance of getting the virus that causes AIDS by not sharing needles with other people?

- Can a pregnant woman infected with HIV or AIDS transmit the virus to her unborn child?

- Can a woman with HIV or AIDS transmit the virus to her newborn child through breastfeeding?

\section{Results}

\section{Bivariate analysis}

\section{Background characteristics}

The weighted sample, which reflect the distribution of the Chinese population in the provinces, was evenly split between males (51 per cent) and females (49 per cent), and ranged in age between 18 and 60 (table 1). Of those in the sample, 19 per cent had elementary schooling or below, about 40 per cent had attended middle school, 27 per cent had high school, secondary school or special technical school education, and 14 per cent had a college degree. After weighting to reflect residence, nearly 60 per cent of the sample ( 58 per cent) were from rural areas, while one quarter ( 28 per cent) lived in cities and 14 per cent lived in towns.

Table 1. Weighted* descriptive statistics

\begin{tabular}{|c|c|c|c|}
\hline Categorical variable descriptive statistics & \multicolumn{2}{|c|}{ Number } & Percentage \\
\hline \multicolumn{4}{|l|}{ Sex } \\
\hline Male & \multicolumn{2}{|c|}{1622} & 51 \\
\hline Female & \multicolumn{2}{|c|}{1568} & 49 \\
\hline \multicolumn{4}{|l|}{ Residence } \\
\hline City & \multicolumn{2}{|c|}{899} & 28 \\
\hline Town & \multicolumn{2}{|c|}{438} & 14 \\
\hline Rural & \multicolumn{2}{|c|}{1853} & 58 \\
\hline \multicolumn{4}{|l|}{ Education } \\
\hline Elementary or below & \multicolumn{2}{|c|}{612} & 19 \\
\hline Middle school & \multicolumn{2}{|c|}{1285} & 41 \\
\hline High school, secondary school, specialized technical & \multicolumn{2}{|c|}{841} & 27 \\
\hline Associates' degree & \multicolumn{2}{|c|}{254} & 8 \\
\hline Bachelors' degree or above & \multirow{2}{*}{\multicolumn{2}{|c|}{175}} & 6 \\
\hline \multicolumn{2}{|c|}{ Continuous variable descriptive statistics (weighted obs: 3 444) } & & \\
\hline Mean & Std. Dev & Min & Max \\
\hline 37.94 & 11.80 & 18 & 60 \\
\hline Knowledge & 1.82 & 0 & 7 \\
\hline
\end{tabular}

* Weights were applied to the data to reflect the distribution of the Chinese population in the provinces. 


\section{Knowledge of HIV}

Most Chinese people have heard of HIV and AIDS - 81 per cent of the entire sample, and 91 per cent of urban residents (not shown in a table). The same percentage of men and women had heard of HIV and AIDS (81 per cent). Young people were more likely than older people to have heard of HIV and AIDS (87 per cent of those aged 26-35 compared with 66 per cent of those aged 56-60). Nearly equal percentages of Chinese (45 and 42 per cent, respectively) noted sexual transmission and blood as the main association they made when thinking about how someone can contract HIV and AIDS, followed by only 3 per cent whose first association was mother-to-child transmission (not shown in a table).

Regarding specific knowledge questions related to transmission and prevention, two thirds of the weighted sample of Chinese residents (66 per cent), knew that one will not be infected with HIV by sharing a meal with an HIV-positive person, while 14 per cent did not know if someone can be infected with HIV through sharing a meal with someone (table 2). Forty per cent of respondents knew that correctly using a condom every time they have sex would protect a person from HIV transmission, ${ }^{4}$ while more than a quarter $(28$ per cent) said consistent condom use could not protect against HIV infection, 24 per cent were not sure, and 7 per cent did not respond to the question. In all, half of those questioned (50 per cent) said that abstinence can reduce one's chance of getting infected by HIV/AIDS, while nearly a quarter of respondents ( 23 per cent) did not think so; 21 per cent were not clear about the relationship between abstinence and HIV infection and 5 per cent did not respond. Almost two thirds (60 per cent) of Chinese residents knew that having sex with just one uninfected partner could reduce their chance of getting HIV, 16 per cent thought that doing so could not, 18 per cent did not know, and 6 per cent did not answer. More than three quarters (73 per cent) of respondents knew that not sharing needles with other people would reduce one's chance of contracting HIV/AIDS, 10 per cent said it would not, 14 per cent did not know, and 1 per cent did not answer. Seventy-five per cent knew that an HIV-infected pregnant woman could transmit the virus to her unborn child; 10 per cent said that it could not; 14 per cent did not know; and slightly more than one per cent did not respond. In addition, nearly two thirds (61 per cent) of Chinese knew that HIV/AIDS can be transmitted to a newborn through breastfeeding, 17 per cent said that it could not, 20 per cent did not know, while nearly 2 per cent did not respond. Table 1 shows that respondents had an average knowledge score of 3.77 correct responses (out of a maximum of 7). 


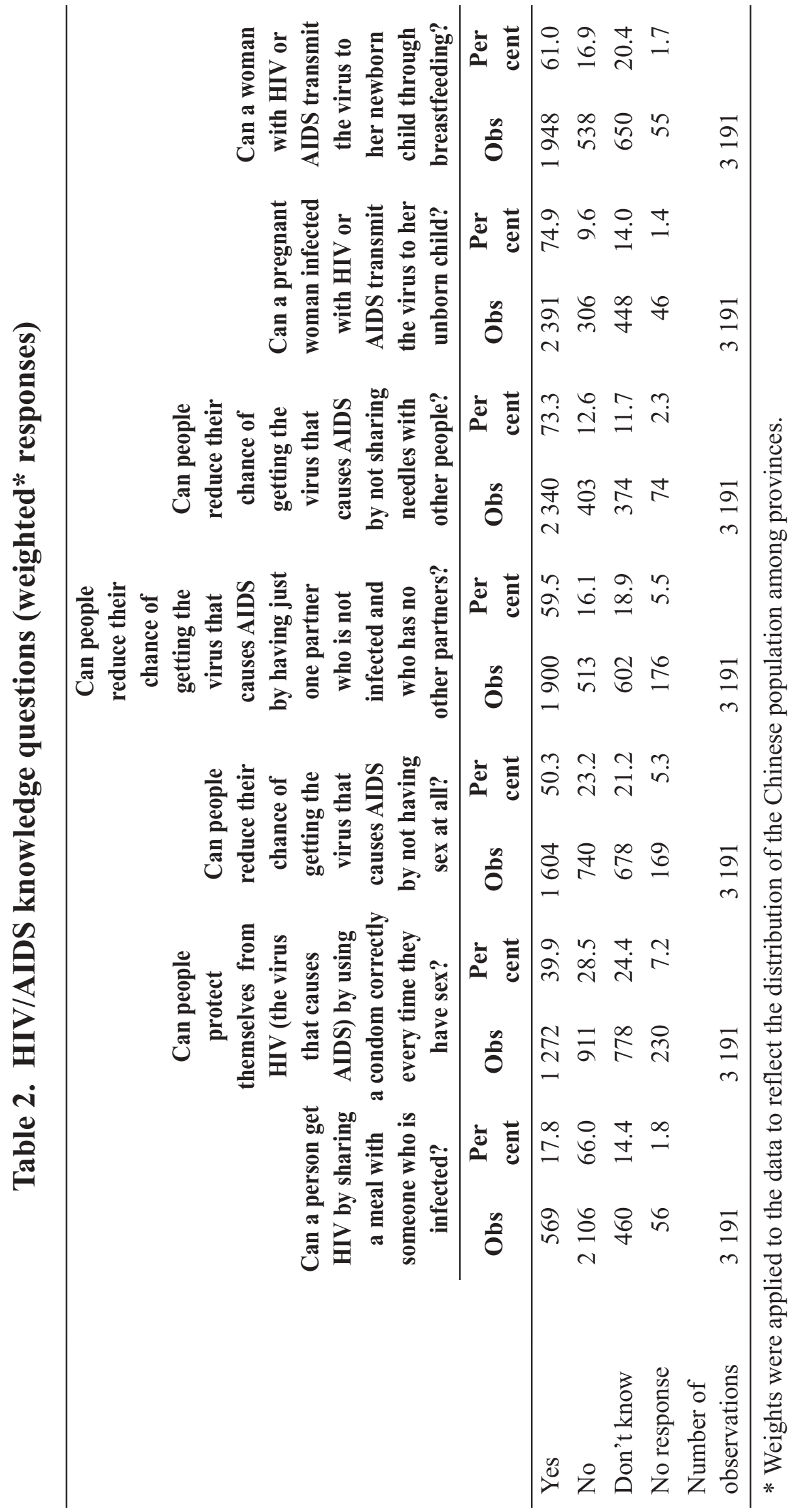




\section{Stigma and discrimination}

The level of stigma and discrimination prevailing among people who had heard of HIV and AIDS was measured through three questions, one regarding a co-worker and two associated with family members (table 3). Most people described discriminatory attitudes towards HIV-positive work colleagues-fully 72 per cent said that an HIV-positive co-worker should not be allowed to continue working, compared with 28 per cent who said they should be able to do so.

\section{Table 3. Indicators of stigma and discrimination (Weighted* responses)}

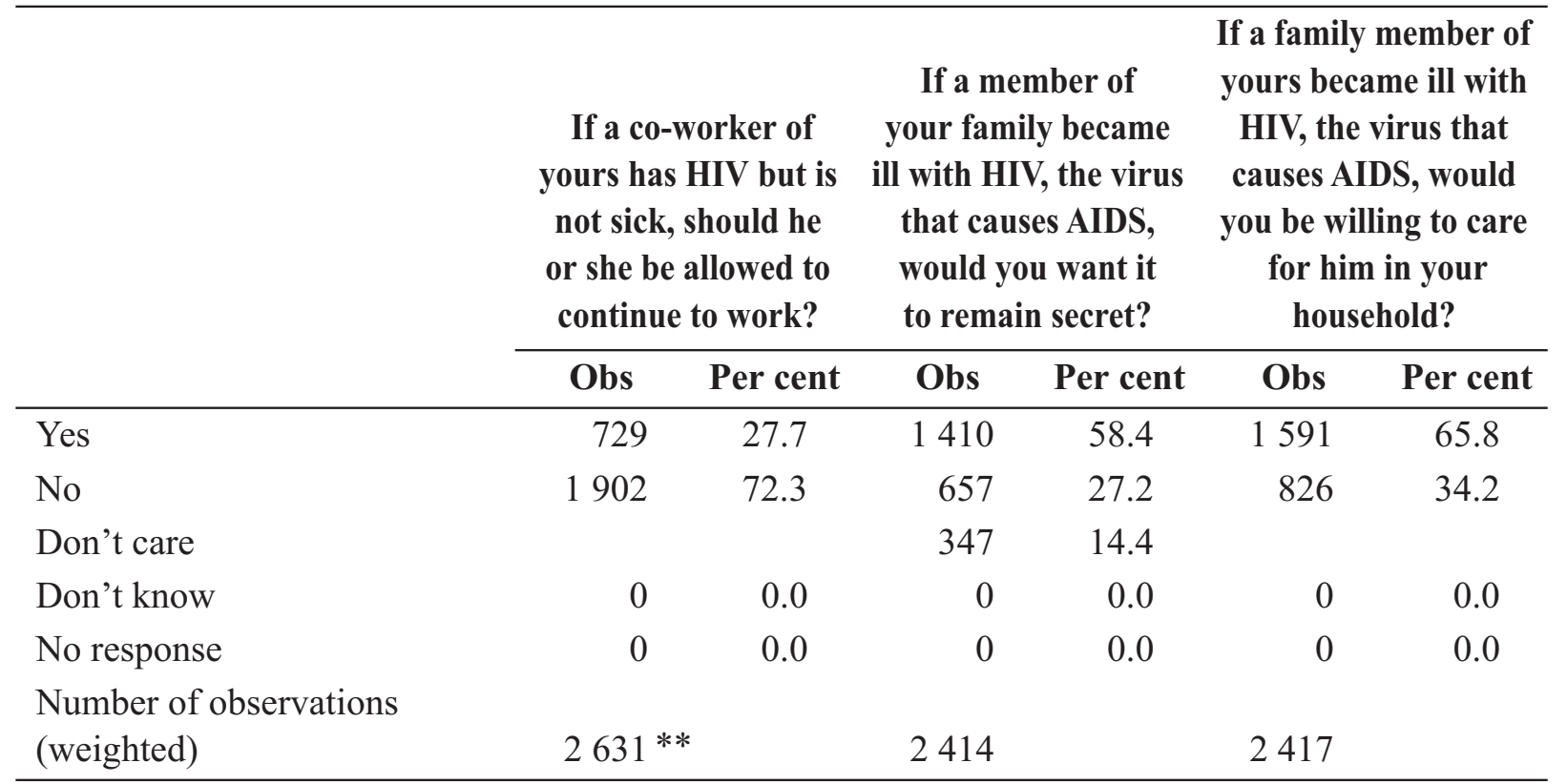

* Weights were applied to the data to reflect the distribution of the Chinese population in the provinces.

** The sample used in this table is the one used in the logistic regression shown in table 4.

The response regarding family members indicated that 66 per cent of Chinese said they would be willing to care for a sick family member, while 34 per cent said that they would not. At the same time, 58 per cent of respondents said they would want the HIV status of the family member to remain secret, while 27 per cent said they would not. A total of 14 per cent said that it did not matter in their views. 


\section{Multivariate analysis relating background characteristics to stigma and discrimination}

The authors ran three multivariate logistic regression models that included age, gender, residence (town, rural, or city), education, and knowledge on HIV as independent variables. In each model, the outcome variable was one of three questions assessing stigma and discrimination.

Tests showed no multiple-collinearity among any of the sets of independent variables. The level of certainty of all significant variables was at least 95 per cent unless otherwise noted. The three models are shown in table 4.

Age: Age was not significant in any of the models.

Sex: The sex of respondent was not significant in any of the models.

Residence: Both town and rural residents are shown to be less likely than the reference group (city residents) to want a co-worker with HIV to be allowed to return to work. Town residents also appeared less willing that city residents to care for a family member with HIV, while both town and rural residents were less likely to be concerned about the status of the family member remaining secret than the city dwellers.

Education: Education appeared to be significant in the model related to caring for a family member infected with HIV but not in the model related to wanting the HIV/AIDS status of their family members remain a secret. In the earlier model, respondents with education above elementary school were generally more likely than those with elementary school or less to say that they would care for a sick family member. Those with senior middle school/secondary specialized/ technical schooling are more likely than those with elementary education to be willing to allow HIV-positive people to stay in their workplace.

Knowledge of HIV: The level of HIV/AIDS knowledge does not appear to shape the opinions on any of the three questions posed, as the variable was not significant in any of the models. 
Table 4. Multivariate analysis of factors related to stigma and discrimination in China

(Odds ratios)

\begin{tabular}{|c|c|c|c|}
\hline \multirow{3}{*}{ Characteristic } & \multicolumn{3}{|c|}{ Questions related to stigma and discrimination } \\
\hline & $\begin{array}{l}\text { Respondents agreeing } \\
\text { with the statement: } \\
\text { A co-worker who } \\
\text { has HIV but is not } \\
\text { sick SHOULD be } \\
\text { allowed to return } \\
\text { to work }\end{array}$ & $\begin{array}{l}\text { Respondents agreeing } \\
\text { with the statement: } \\
\text { If a member of your } \\
\text { family became ill } \\
\text { with HIV, the virus } \\
\text { that causes AIDS, you } \\
\text { WOULD you want it } \\
\text { to remain secret }\end{array}$ & $\begin{array}{l}\text { Respondents agreeing } \\
\text { with the statement: } \\
\text { If a family member } \\
\text { of yours became ill } \\
\text { with HIV, the virus } \\
\text { that causes AIDS, } \\
\text { you WOULD you be } \\
\text { willing to care for } \\
\text { him in your household }\end{array}$ \\
\hline & Odds ratio & Odds ratio & Odds ratio \\
\hline \multicolumn{4}{|l|}{ Age } \\
\hline Continuous variable (years) & $\begin{array}{c}0.99 \\
(0.98-1.00)\end{array}$ & $\begin{array}{c}0.99 \\
(0.98-1.01)\end{array}$ & $\begin{array}{c}1.00 \\
(0.99-1.01)\end{array}$ \\
\hline \multicolumn{4}{|l|}{ Sex (reference category: female) } \\
\hline Male & $\begin{array}{c}1.18 \\
(0.93-1.50)\end{array}$ & $\begin{array}{c}0.9 \\
(0.71-1.14)\end{array}$ & $\begin{array}{c}1.18 \\
(0.92-1.51)\end{array}$ \\
\hline \multicolumn{4}{|c|}{ Residence (Reference category: urban resident) } \\
\hline Town resident & $\begin{array}{c}0.44 \\
(0.35-0.55)^{* *}\end{array}$ & $\begin{array}{c}0.39 \\
(0.32-0.48)^{* *}\end{array}$ & $\begin{array}{c}0.66 \\
(0.53-0.83)^{* *}\end{array}$ \\
\hline Rural resident & $\begin{array}{c}0.47 \\
(0.35-0.63)^{* *}\end{array}$ & $\begin{array}{c}0.53 \\
(0.40-0.69)^{* *}\end{array}$ & $\begin{array}{c}0.78 \\
(0.59-1.03)\end{array}$ \\
\hline \multicolumn{4}{|c|}{ Education (Reference category: elementary school or lower) } \\
\hline Middle school & $\begin{array}{c}1.42 \\
(0.91-2.23)\end{array}$ & $\begin{array}{c}1.3 \\
(0.87-1.94)\end{array}$ & $\begin{array}{c}1.9 \\
(1.29-2.82)^{* *}\end{array}$ \\
\hline $\begin{array}{l}\text { Senior middle school/ } \\
\text { secondary specialized/technical }\end{array}$ & $\begin{array}{c}1.65 \\
(1.02-2.67)^{*}\end{array}$ & $\begin{array}{c}1.27 \\
(0.82-1.96)\end{array}$ & $\begin{array}{c}1.45 \\
(0.94-2.24)\end{array}$ \\
\hline Some college & $\begin{array}{c}1.61 \\
(0.93-2.80)\end{array}$ & $\begin{array}{c}1.46 \\
(0.86-2.48)\end{array}$ & $\begin{array}{c}1.99 \\
(1.16-3.40)^{*}\end{array}$ \\
\hline University graduate and higher & $\begin{array}{c}1.68 \\
(0.93-3.03)\end{array}$ & $\begin{array}{c}1.15 \\
(0.64-2.05)\end{array}$ & $\begin{array}{c}3.33 \\
(1.74-6.36)^{* *}\end{array}$ \\
\hline $\begin{array}{l}\text { Knowledge of HIV/AIDS score } \\
\text { Continuous variable }(0-7)\end{array}$ & $\begin{array}{c}1.07 \\
(0.99-1.15)\end{array}$ & $\begin{array}{c}1.07 \\
(1.00-1.14)\end{array}$ & $\begin{array}{c}1.03 \\
(0.96-1.11)\end{array}$ \\
\hline Observations & 2763 & 2659 & 2595 \\
\hline McFadden's R2 & 0.041 & 0.029 & 0.023 \\
\hline McFadden's Adjusted R2 & 0.035 & 0.023 & 0.017 \\
\hline
\end{tabular}

Robust 95 per cent confidence intervals are shown in parentheses.

* indicates significant at 5 per cent; ** significant at 1 per cent. 


\section{Discussion}

The main finding of this paper is the consistency of generally negative views among the Chinese population regarding people living with HIV and AIDS. The findings of this nationally representative sample of Chinese provide validation of the smaller studies conducted on the topic to date. While this survey of adult Chinese men and women could not explore in depth the issue of stigma and discrimination, a distinction clearly emerged between related to familial relationships and that related to attitudes societal relationship. Similar results were found in an earlier study conducted among sex workers and adult men in Sichuan and Yunnan provinces (Horizon Market Research and Futures Group Europe, 2002a and 2002b). ${ }^{5}$ The low percentages of people indicating that a co-worker should be "allowed" to return to work with a diagnosis of HIV indicates that the Chinese population is not comfortable with the notion of working among HIV-positive colleagues - and that they condone a level of discrimination in the public sphere against people living with HIV and AIDS. The fact that the only statistically significant difference found among respondents regarding their views that an HIV-positive co-worker should not return to work was town residence indicates remarkably consistent (negative) views. A study of AIDS-related discrimination in the workplace in Hong Kong, China, showed similar reluctance to welcome an HIV-positive colleague in the workplace (Lau and Wong, 2001).

The high correlation between the percentages of those who would want to care for a family member and those who would want the HIV status of the family member to remain secret shows a paradoxical view among Chinese residents regarding HIV/AIDS. It is likely that while many people consider it a duty to care for a sick family member, they consider having an HIV-positive family member as shameful and equivalent to 'loosing face' in public. It is noteworthy that the most significant differences were found in the models related to family members.

These findings are important for the design and implementation of Chinese HIV and AIDS programmes. This study reinforces the views that HIV-related stigma and discrimination are pervasive among various demographic and residential groups in China. Interventions to reduce stigma and discrimination should be based on these shared norms and public opinion. Because stigmatizing and discriminatory attitudes and tendencies are largely prevalent in China, and because every province in China is home to PLHA, national and local mass media interventions have an important role to play in making Chinese citizens aware of the debilitating effects of stigma and discrimination and in reinforcing information 
on HIV/AIDS to reduce baseless fears of transmission from family members and work colleagues (and by extension, students, etc). Politicians and opinion leaders have important roles to play in dispelling myths and changing attitudes. For example, Chinese Premier Wen Jiabao received positive press coverage when he visited the Beijing Ditan Hospital on World AIDS Day in 2003 and became the first senior Chinese government official to shake hands with a person living with HIV/AIDS (Gill, Morrison and Thompson, 2004). More intensive interventions should be directed to the majority of Chinese who live in rural areas, including through mass media, social marketing workplace programmes and interventions to support family caregivers, and enforcement of laws protecting PLHA. The International Labour Organization has recorded successful examples of such workplace programmes (ILO, 2001; ILO, 2008). Given the pervasive views regarding PLHA, China has a unique opportunity to mount a national response to reduce stigmatizing and discriminatory attitudes and behaviour. 


\section{Endnotes}

1. Authors initially intended to examine the effects of respondents' HIV-related risk behaviour and their perceptions on stigma and discrimination; however small sample sizes associated with those variables prohibited such analysis. Few Chinese (4 per cent) considered themselves at medium or high risk of HIV, which is not surprising given the low national estimate for HIV prevalence. Furthermore, few people ( 2 per cent) in the sample indicated that they had had multiple partners in the month prior to the survey (although nearly one quarter of the respondents chose not to answer that particular question). Income as an independent variable had also been considered for inclusion; however income ranges for urban and rural areas were so broad that it would have required separate analysis for urban and rural areas. Likewise, authors intended to include occupation in the analysis, but it was not possible to reconcile occupational categories across rural and urban areas.

2. While a survey dedicated to HIV and AIDS could have yielded more in depth information on stigma and discrimination, use of omnibus surveys to collect a small set of information on a topic is a cost-effective way of getting representative findings over large study areas. Such surveys can provide data to validate or complement smaller-scale surveys and in-depth investigations.

3. Eleven respondents from the rural sample aged less than 18 were excluded from the study to align the rural and city samples.

4. This finding is not surprising given China's stringent family planning programme that has never promoted the condom as an effective means of preventing pregnancy.

5. That study also found that a family member with HIV would be perceived differently if the virus was contracted through sex or through blood with the latter more tolerable than the former. The current study was not able to go into such detail regarding stigma and discrimination. 


\section{References}

Agence France Presse (2002). "China-AIDS: Chinese city passes law to protect rights of AIDS patients", 16 October 2002.

APN+ (2004). AIDS Discrimination in Asia, Bangkok: Asia Pacific Network of People Living with HIV and AIDS.

Avert.org. (2004). HIV \& AIDS in China, http://www.avert.org/aidschina.htm, accessed on 20 February 2004.

Brown, L., K. MacIntyre and L. Trujillo (2003). "Interventions to Reduce HIV/AIDS Stigma: What Have We Learned?", AIDS Education and Prevention, vol. 15, No. 1, pp. 49-69.

Chen J., M. Choe M.K., S. Chen and S. Zhang (2005). "Community Environment and HIV/AIDSRelated Stigma in China", AIDS Education and Prevention, vol. 17, No. 1, pp. 1-11.

Family Health International (FHI) and DfID (2000). Behavioral Surveillance Survey (BSS), Guidelines for Repeated Behavioral Surveys in Populations at Risk of HIV.

Gill, B. (2002). Testimony before the Congressional-Executive Commission on China Roundtable on HIV/AIDS.

Gill, Bates, J. Stephen Morrison and Drew Thompson (2004). Defusing China's Time Bomb: Sustaining the Momentum of China's HIV/AIDS Response, a report of the Center for Strategic and International Studies HIV/AIDS Delegation to China, 13-18 April 2004, http:// www.hivpolicy.org/Library/HPP000649.pdf, accessed on 28 September 2009.

Goffman, E. (1963). Stigma: Notes on the Management of Spoiled Identity, New York: Simon and Schuster.

Horizon Research Consultancy Group and Futures Group Europe (2004). AIDS Crisis Impending: Research on Knowledge, Attitudes and Behaviors Related to HIV/AIDS in China, Beijing: Horizon Research Consultancy Group and Futures Group Europe.

Horizon Market Research and Futures Group Europe (2002a). Behavioural Surveillance Survey in Yunnan and Sichuan, China. Adult Male Report, Beijing: Horizon Research and Futures Group Europe.

(2002b). 2001 Behavioural Surveillance Survey in Yunnan and Sichuan, China. Sex Worker Report. Beijing: Horizon Research and Futures Group Europe.

International Labour Organization (ILO) (2001). ILO Code of Practice on HIV/AIDS and the World of Work. Geneva: ILO, http://www.ilo.org/public/english/protection/trav/adis/code/ languages/hiv_a4_e.pdf, accessed on 6 August 2008.

(2008). International HIV/AIDS Workplace Education Programme, SHARE: Strategic HIV/AIDS Response in Enterprises, Second Report, http://www.ilo.org/public/english/ protection/trav/adis/code/languages/SHARE08.pdf, accessed on 6 August 2008.

Kaufman, J. and J. Jing (2002). "China and AIDS - The Time to Act is Now", Science, 28 June 2002, p. 2339. 
Kish, L. (1965). Survey Sampling, New York, J.W. Wiley and Sons, Inc.

Lau, J.T. and W.S. Wong (2001). "AIDS-related discrimination in the workplace - the results of two evaluative surveys carried out during a three-year period in Hong Kong", AIDS Care, vol. 13 , No. 4 , pp. $433-440$.

Malcolm, A., P. Aggleton, M. Bronfman, J. Galvao, P. Mane, and J. Verrall (1998). "HIV-related stigmatization and discrimination: Its forms and contexts", Critical Public Health, vol. 8, No. 4, pp. 63-79.

Mann, J. (1987). Statement on an Informal Briefing to the $42^{\text {nd }}$ Session of the United Nations General Assembly, New York.

Parker, R and P. Aggleton (2002). HIV and AIDS-related Stigma and Discrimination: A Conceptual Framework and Implications for Action, Rio de Janerio, ABIA.

Parker, R., and others (2002). Sexual Health Exchange HIV/AIDS-related Stigma and Discrimination: A Conceptual Framework and an Agenda for Action, Washington, D.C., Population Council Horizons Project.

Pulerwitz, J., J. Greene, E. Esu-Williams and R. Stewart (2004). "Addressing Stigma and Discrimination in the Workplace: The Example of ESKOM, South Africa", Sexual Health Exchanges 2004-2, pp. 9-10.

Reidpath, D.D., B. Brijnath and K.Y. Chan (2005). "An Asia Pacific six country study on HIV-related discrimination: Introduction”, AIDS Care, No. 17 (Supplement 2), S117-S127.

Rosenthal, E. (2003). "Despite law, China's HIV patients suffer bias", New York Times, 14 January 2003.

UNAIDS (2001). "Stigma and Discrimination Fuel AIDS Epidemic, UNAIDS Warns", Press Release, Geneva: UNAIDS, 5 September 2001.

(2006). 2005 Update on the HIV/AIDS Epidemic and Response in China, Beijing: Ministry of Health, People's Republic of China, Joint United Nations Programme on HIV/AIDS and World Health Organization.

(2008). International Labour Organization in Vietnam, Description of an ILO study on stigma in the workplace in Vietnam, http://www.unaids.org/about/cosponsor/ilo.htm, accessed on 8 May 2008. Also see "HIV/AIDS Discrimination in Workplace Widespread in Vietnam, ILO Study Says", reported on kaisernetwork.org and reprinted on http:// thebody.com/content/art11869.html, accessed on 8 May 2008.

White, K.J.C. and A.M. Guest (2003). "Community Lost or Transformed? Urban and Social Ties", City \& Community, 2 September 2003, pp. 239-259.

WHO (2008). Second Generation Surveillance for HIV/AIDS. http://www.who.int/hiv/topics/ surveillance/2ndgen/en. Accessed on 22 July 2008. 